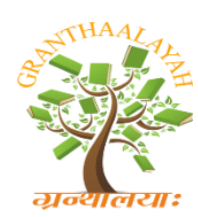

INTERNATIONAL JOURNAL OF RESEARCH GRANTHAALAYAH A knowledge Repository

Social

\title{
REVAMPING PRE-SERVICE TEACHER EDUCATION UNDER NEW NCTE NORMS 2014: PERCEPTION OF B.ED. STUDENTS TOWARDS INCREASED DURATION OF COURSE
}

\author{
Shabir Ahmed ${ }^{1}$, Ahakesh Sharma ${ }^{2}$ \\ ${ }^{1,2}$ Department of Educational studies, Central University of Jammu, India
}

DOI: https://doi.org/10.29121/granthaalayah.v5.i6.2017.2002

\begin{abstract}
Today India is having one of the largest networks of schools in the world. School education is most important stage in the whole educational ladder and underwent transformation since independence. For say after independence government of our country stressed on quantitative expansion of school education so as to provide access of education to the students in their door steps but in 21 st century focus is shifted from quantity to quality of school education. This shift of paradigm and ICT revolution made the job of teacher more demanding. Quality of school education is depending on quality and professional commitment of teachers and quality of teachers depend upon nature and type of pre-service teacher training to prospectus teachers. Keeping pace with the needs of present time, in 2012 Verma committee recommended number of changes in the pre-service teacher education programme and enhancing duration was one of them. Hence, National Council of Teacher Education (NCTE) came up with new regulation in 2014 under which duration of B.Ed. and M.Ed. was increased from initial one year to two years. The new NCTE regulations are implemented all over the nation from academic session 20152016. However, the implementation of new NCTE norms has given a way to the debate on the credibility of increased duration of both the courses. The present paper will appraise the probable benefits and issues related with the increased duration of the pre-service teacher training programmes as per the NCTE Regulations 2014.
\end{abstract}

Keywords: NCTE; Regulation; Teacher Education; Profession; Teacher.

Cite This Article: Shabir Ahmed, and Ahakesh Sharma. (2017). "REVAMPING PRE-SERVICE TEACHER EDUCATION UNDER NEW NCTE NORMS 2014: PERCEPTION OF B.ED. STUDENTS TOWARDS INCREASED DURATION OF COURSE." International Journal of Research - Granthaalayah, 5(6), 92-101. 10.29121/granthaalayah.v5.i6.2017.2002.

\section{Introduction}

"My dearest and nearest relative in life is my Guru; next, my mother; then my father. My first reverence is to the Guru. If my father says, "Do this", and my Guru says, "Do not do this", I do 
not do it. The Guru frees my soul. The father and mother give me this body; but the Guru gives me rebirth in the soul."

(Swami Vivekananda)

Teacher Education means the preparation of teachers for the profession of teaching and it is a well-known saying that the quality of education of a country depends upon the quality of teachers and the quality of teachers depends upon the quality of training in the teacher training institutes. Keeping in view the above quoted lines the training of teachers acquires great importance in the education system of any country. Teacher Education in India has seen a gradual growth since independence. Although teacher education institutes existed even before independence but their number was meager keeping in view the needs of the country. After independence teacher training institutes in India underwent all the needed expansion along the length and breadth of the country. The report of every commission and committee appointed after 1947 emphasized the need of quality teacher training for the improvement of education system of the country which resulted in setting up of a range of educational institutions including schools and teacher training institutions. Teacher education is important not from the point of view of equipping prospective teachers with required professionalism but also develop them into teachers who can bring required improvement and effectiveness in the education According to Shulman (Knowledge and Teaching: Foundations of New Reforms, published in Harvard Educational Review, 1987), a teacher should possess subject content knowledge, general pedagogical knowledge, and the knowledge of educational contexts and goals; and should be able to use this knowledge creatively to deal with ever changing classroom situations. Now-adays many new trends are emerging in the school education like introduction of comprehensive and continuous system of evaluation, participatory and interactive learning, reflective teaching etc. and to keep pace with the changes the teacher education has to be dynamic. Students have became the pivotal point if the education. Gone are the days when teacher needed to spoon-feed the students now one has to simply expose the child to the topic so that it is understood from their own perspective. Learning should not be terror for the students it should be an enjoyable experience for them. Keeping in view the changing trends the teacher education also need to undergo constant changes.

National Council of Teacher Education (NCTE) is an apex body set up by government of India in 1995 through the National Council for Teacher Education Act, 1993 for development of teacher education in India. It is responsible for maintaining the norms and standards in teacher education system at different levels of school system. NCTE work under ministry of Human Resource and Development, (HRD) Govt. of India. According to a study by NCTE (Critique, Dimensions and Issues in Teacher Education), from a meager 10 secondary teacher training institutions in 1948, the number increased to 50 in 1965 and 633 by 1995. As on March 31, 2010, the total number of institutes imparting all kinds of teacher education programmes came to 11,712 .

\section{History of Teacher Education in India}

The history of teacher education in India can be discussed under the perspective of two different eras: 


\section{Teacher Education in Pre-Independence Era}

Although any discussion of education in India starts with education in the Vedic period but the education of teachers is not that old. Its very roots can be traced back only to 1716 when Danish missionaries started teacher training institutes in Tranquebar. After that normal schools were opened at Serampore in 1793. With the objective of improving quality of teacher education in India, the British government appointed number of committees and commissions which are as under-

Wood's Dispatch (1854): Known very famously as the magna carta of Indian education woods dispatch emphasized the importance of training of teachers and recommended for the establishment of the same.

Hunter Commission (1882): This commission recommended that for raising the standards of education proper training of teachers is very important and recommended the opening of normal schools in for the training of teachers and also made separate provision for training of graduate and undergraduate teachers.

Government resolution of (1904): The government of India resolution recommended highly qualified and trained staff for training colleges, one year's training for graduates and two year training course for under graduates and others.

Sadler Commission (1916-1917): Sadler commission recommended that number of trained teachers should be increased and subject of education should be included in the curriculum of B.A.

Hartog Committee (1929): This committee recommended that training period of teachers should be extended, training institutes should have better and more efficient staff, pedagogy and methods of teaching should be improved.

Sargent Report (1944): Sargent report recommended that boys and girls suitable for the profession of teaching should be selected during their high school course, courses should be practical and need based, two year duration for the training of undergraduate teachers i.e. preprimary, junior basic and senior basic teachers and one year training for graduate teachers.

\section{Teacher Education in the Post-Independence Era}

University education commission (1948-1949): The first commission on education after independence recommended that in teacher's training more weightage should be given to school practice and the students should be encouraged to proceed to M.Ed. course after some years of teaching experience.

Secondary education commission (1953-1954): Commission recommended two type of training institutes i.e. teacher training institutions for graduates and the duration of course should be one year and training schools for undergraduates and duration of course should be two year, provision of more practical training, in service training etc.

Indian education commission (1964-1966): This commission recommended to improve teacher education by removing isolation training, by improving professional education and by improving the quality of training institutes, recommended professionalization of Teacher Education, Comprehensive Colleges of Internship and focused on development of integrated programmes.

Chattopadhyay committee report (1983-1985): The committee recommended that If teacher education is to be made relevant to the roles and responsibilities of the New Teacher, the 
minimum length of training for a Secondary teacher should be five years following the completion of Class XII, an integrated four year programme which should be developed carefully, establishment of education department in the existing science and arts colleges, B.Ed. programme should be extended by two summer months having a total of 220 days in an academic session with longer working hours.

National policy of education (1986): NPE 1986 recommended that teacher education is a continuous process, in-service and pre-service cannot be separated, establishment of D.I.E.T, N.C.T.E will be provided resources and capability to accredit teacher training institutes,

Ramamurti Review committee (1990): This committee pointed out that the present programme is theory oriented, practice teaching period allotted is not adequate in terms of duration and experience gained, there is little or no scope for improving the affective domain of teaching, inadequate infrastructure, minimum emphasis on developing skills etc.

Revised National Policy of Education (1992): The revised policy recommended that teacher training and selection should be improved and emphasis should be placed on teachers accountability, upgradation of secondary teacher education institutes into institute of advanced studies (IASE), autonomous status to SCERTs. NCTE should be given statutory status.

National Curriculum Framework For Teachers (NCFTE-2009): NCFTE recommended that teacher education should integrate academic knowledge and professional learning, teacher education should engage teachers with the curriculum, syllabi and textbooks, teacher education should provide opportunity to trainees for reflection and independent study, it should engage teachers with children in real contexts than teach them about children through theories.

Justice Verma Committee (JVC 2012): Committee gave many important recommendations regarding the reformation of Teacher Education. It recommended pre-entry testing of candidates, duration of programme of teacher education needs to be enhanced, redesigning of the current teacher education programme in the light of NCFTE 2009, attachment of a laboratory school with every pre-service training institute, the first professional degree/ diploma in teacher education should be offered only in face -to -face mode, enhanced investment in promotion of research in education.

\section{Background of Debate on Duration}

- Kothari Commission (1964-66): Commission was of the view that elementary teacher education programme should be of 2 years duration and secondary teacher training of one year. But in an academic year, in its view, there should be at least 230 working days in the one year B.Ed. programme. For M.Ed., it recommended 3 years period instead of existing one year.

- Chhattopadhyay Committee (1983): The committee recommended the following recommendations regarding duration of pre-service teacher education programmes:

$>5$ year training for secondary teachers after completion of class $12^{\text {th }}$.

$>$ Integrated 4 year programme for both the secondary and elementary pre-service teacher education.

$>$ B.Ed. programme should be extended by two summer months having a total of 220 days with longer working hours in a session.

- Ramamurti Committee (1990): Committee observed keeping in view the present scenario of teacher education programme there in a need to revamp the present programme because the time allotted for practice of teaching is not sufficient. 
- Yashpaul Committee (1993): The duration of the programme should either be one year after graduation or three-four years after higher secondary.

- NCF (2005): The teacher education programmes should be ideally of 5 years duration after the completion of $10+2$ level of school education.

- NCFTE (2009): Considering the complexity and significance of teaching as professional practice, it is imperative that the entire enterprise of teacher education should be raised to university level and the duration and the rigor of programmes should be appropriately enhanced and for the same it recommended either a four year integrated model at the bachelor's degree level or two year second bachelor's degree programme. It also recommended internship in schools for 6-10 weeks for 2 year programme and 15-20 weeks for two year programme.

- Justice Verma Committee (2012): Teacher Education to be a part of the higher education system. The duration of the programmes of Teacher Education needs to be enhanced, in keeping with the recommendations of the Education Commission (1966), the implementation of which is long overdue.

\section{Relation of Increased Duration of B.Ed. Course and Quality Teachers}

Teachers are the backbone of any system of education. Of all the factors that influence the quality of education, the quality of teachers is undoubtedly the most significant. "Quality of teachers mainly refers to the teachers' competency in the subject that he/she deals with, expertise to use methods and techniques of teaching, ability to understand learners' problems and the teachers attitudinal makeup." (Pradhan, 2001). Quality of teachers to a large extent determines the quality of education being imparted in our educational institutions and to enhance the quality of education, it is important to have quality teachers and to have quality teachers it is important that the their training is effective enough to ensure quality. So the aim of teacher education institutions should rather be to produce quality teachers and instill the prospective teachers with all the required skills during their respective training. Subsequent commissions and committees on education till now have regarded the period of one year for the training of teachers as insufficient. Most of the times the short duration of the course forces training institutes to compromise with the skills imparted, their focus shifts to complete the course in time which means we are able to produce more and more teachers every year but somehow quality is being compromised. It has been discussed for a long time that the duration of the B.Ed. course should be increased because increased duration simply means more time for theory orientation, more time for teaching skills, more time for teaching practice. With the increased duration the training institutes can on all the necessary areas to develop quality teachers which they were not able to focus on due to lack of time. So the increased duration is an opportunity for training institutes to develop quality teachers in their respective institutes.

\section{Need and Significance of the Study}

NCERT introduced two year B.Ed. course in its four wings from session 1999-2000 in accordance with NCTE guidelines. Since then this course is continuing in these four RIEs keeping in view many hopes and aspirations. The two-year B.Ed. program introduced by NCERT in its RIEs has certain special features/characteristics. It provides greater scope for development of sound knowledge on different areas i.e. content knowledge, knowledge on 
teaching-learning methodologies and knowledge on pedagogy of teaching learning among the trainee-teachers. It develops a sound knowledge base for trainee-teachers in content areas, develops skills of trainee-teachers to be competent enough regarding how to transact the content materials to the students of the schools meaningfully.

In 2014 NCTE came up with new regulations for the in-service teacher training programmes under which it increased the duration of B.Ed. and M.Ed. courses from 1 year to two years. These norms are applicable on all teacher education institutions throughout India henceforth the duration of both the course is extended to two years.

Two years are already passed since the implementation of new regulation and it seems to be the right time to analyse that whether the decision is accruing the benefits or not. Thus, a study was planned to find out benefits and issues experienced by pupil teachers who have been exposed to the increased duration. The students of the $3^{\text {rd }}$ semester of B.Ed. course (Academic session 201516) enrolled in different teacher education colleges were approached for the purpose and data was collected using a self-made questionnaire indicating two statements i.e. one of benefits of increased duration and other indicating issues regarding the same. For each statement the respondents were asked to give 5 views and on the basis of their recorded responses inferences were made.

\section{Objectives of the Study}

The study will fulfill following objectives:

i. To study perception of B.Ed. Students about two year Pre-service teacher training programme.

ii. To study the benefits and challenges of implemented two year B.Ed. programme under new NCTE norms 2014.

iii. To suggest remedial measures to deal with the emerging challenges due to increased duration of course.

\section{Detailed Design of the Study}

\section{Population of the Study}

The population for the present study comprised of All B.Ed. pupil teachers of Jammu District of $\mathrm{J} \& \mathrm{~K}$ state.

\section{Sample and Sampling Procedure}

Sample of this study consist of 60 students from 3 B.Ed. colleges of Jammu district. The sample is derived from the population by using purposive sampling technique.

\section{Tool of the Study}

For this study the investigators used self-made open ended questionnaire.

\section{Analysis of Data}

Data is analyzed by using percentage technique. 


\section{Discussion of Results}

Perceived Benefits of Increased Duration
\begin{tabular}{|l|l|l|}
\hline S.No. & RESPONSE CATEGORIES & RESPONSE LOADING \\
\hline 1 & Better knowledge and experience & $83.33 \%$ \\
\hline 2 & $\begin{array}{l}\text { Sufficient time for teaching practice. } \\
\text { Effective Interaction and Understanding Between Teacher } \\
\text { Educators and Pupil Teachers and Among Pupil Teachers. }\end{array}$ & $36.66 \%$ \\
\hline 4 & Enriched Curriculum & $20 \%$ \\
\hline 5 & Increased Field Activities & $46.66 \%$ \\
\hline 6 & Developing Professionalism Among Pupil Teachers & $53.33 \%$ \\
\hline 7 & Semester System Reduces burden & $8.33 \%$ \\
\hline
\end{tabular}

- $\mathbf{8 3 . 3 3} \%$ of pupil teachers believe that two- year B.Ed. course is helpful in gaining better knowledge and experience of various aspects of the course as now they have enough time to master different skills needed to execute professional roles more judiciously.

- $\mathbf{4 5 \%}$ of pupil teachers think that increased duration of B.Ed. course has provided them with ample time for teaching practice as new revised curriculum makes provision for 20 week internship programme which ultimately give them more enriched experience of actual conditions prevailing in the school.

- $\mathbf{8 . 3 3 \%}$ of pupil teachers think that introduction of semester system as a result of increased duration reduced burden on the part of pupil teachers. They further explained that earlier curriculum was heavily loaded with theory and practice which was impractical to complete within one year duration and now as the syllabus is divided into four semesters it is not as heavily loaded as previous one. Hence, pupil teachers and teacher educators have not to be in a hurry to complete the same.

- 36.66\% pupil teachers held that increased duration facilitate more interaction and understanding between teacher educators and pupil teachers and among pupil teachers because now both the stakeholders have enough time to discuss current events and trends in addition to the course content which will develop good communication skills, quality of tolerance and ability to build healthy human relationships. They also held that teachers have more time to use various technologies in the classroom to enrich their lesson and facilitate better teaching and learning and this could be because of the fact that now both teacher educators and pupil teachers have enough time to make learning more interesting, interactive and joyful

- 20\% pupil teachers believe that the revised curriculum in the two year course is enriched and more appropriate according to present need and demands of teaching profession as revised curriculum has incorporated gender education, yoga education, ICT and inclusive education as an integral part of the course. Inclusion of all these new aspects in the curriculum makes it more comprehensive and appropriate to the present scenario. 
- $\quad$ 46.66\% pupil teachers replied that one of the advantage of increased duration is that the revised syllabus make provision for visits to DIET's, SIE, radio stations, anganvadis, and other places of educational importance and this could give firsthand knowledge to pupil teachers and help them in getting deeper insight and more understanding about structure and functions of such institutions

- 53.33\% pupil teachers believe that two year duration is required to infuse multidimensional skills among teacher trainees so that they will develop the sense of professionalism and be able to execute the multiple roles being played by teacher as there is no professional degree which can be completed in meager one year duration.

Perceived Issues Related to Increased Duration

\begin{tabular}{|l|l|l|}
\hline S.No. & RESPONSE CATEGORIES & RESPONSE LOADING \\
\hline 1 & Increased Cost & $55 \%$ \\
\hline 2 & Lengthy Syllabus & $60 \%$ \\
\hline 3 & $\begin{array}{l}\text { Increased Duration is Useless (Should be of 1 year) } \\
\text { Among Different Stakeholders }\end{array}$ & $63.33 \%$ \\
\hline 4 & $\begin{array}{l}\text { Bismanagement, Mess, and Confusion about Syllabus } \\
\text { Poredom and frustration for students. }\end{array}$ & $33.33 \%$ \\
\hline 6 & Reduced Popularity of Course Among Aspirants & $65 \%$ \\
\hline 7 & Shortage of Books as per New Syllabus & $31.67 \%$ \\
\hline
\end{tabular}

- 55\% pupil teachers remarked that increased duration has also increased the cost which ultimately had negative effect on the aspiration of students especially belonging to low and average SES (Socio-Economic Status), though they are bright in studies, might show less interest towards the course. It also increases the cost on part of the university and the central government

- 60\% pupil teachers believe that revised syllabus as per new norms is lengthy. They explained that according to the new norms they have to complete both theory and practice work in a semester of six months duration and in every semester they hardly get four or four and half months to do the same. They are facing shortage of time in each semester to complete the prescribed course which has lead to stressful situations for them in each semester.

- $\quad \mathbf{6 3 . 3 3 \%}$ pupil teachers held that one year duration was sufficient enough for B.Ed. and increased duration is sheer wastage of one precious year of their career and if two summer months are included in the academic session (total of 220 working days) as recommended by Chottopadhyaya Commission in 1985, even one year B.Ed. course will be sufficient.

- $\quad$ 48.33\% pupil teachers observed that there is mismanagement, mess, and confusion about syllabus among different stakeholders. Activities are conducted one after the other without any proper planning which makes it more hectic for the students as 2015-16 
academic session was experimental session it is obvious that some issues will be visible due to the switching one system from one system (one year duration) to another (2 year duration).

- $\mathbf{3 3 . 3 3 \%}$ pupil teachers believe that increased duration has created boredom and frustration on the part of students as they are experiencing continuous repetition of course content semester after semester. They further claimed that mere repetition is not going to yield any fruitful results.

- $\quad 31.67 \%$ pupil teachers remarked that increasing the duration has caused a downfall in the popularity of the course among aspirants which resulted in vacant seats in many teacher education institutions. In 2015, Singh found that "Due to extended duration of one year to 2 years disenchantment has been created among the students which has caused large number of vacant seats in the B.Ed colleges this year. There has been sudden fall in enrollment of students. It approximately ranges from $0 \%$ to $80 \%$ of the total intake capacity of an institution".

- 65\% pupil teachers experienced improper material and non-material resources in the institutions as there is shortage of teachers, shortage of classrooms, unavailability of good books etc. There is shortage of updated books as per the new syllabus both in Hindi and English medium. In the matter of books pupil teachers with Hindi medium have been the worst sufferers. The institutions are also lacking in experienced faculty members who are able to carry forward the course as per new norms and syllabus.

\section{Suggestions}

- Four year integrated B.A/B.Sc/B.Com-B.Ed course should be started so that probability of chance based teachers can be minimized.

- Three year integrated B.Ed.-M.Ed. course should be started to save one precious year of the aspirants.

- Students should not be made liable to pay the extra expenses for the field trips.

- NCTE should take responsibility to publish quality books both in Hindi and English language so that the students may not feel the shortage of required books.

- The management and administration wing of every training institution should prepare academic calendar and all other stakeholders are made to strictly follow the same to avoid confusion and frustration on the part of students and teachers.

- In the case of $\mathrm{J} \& \mathrm{~K}$, minimum qualification for the post of teacher is either $12^{\text {th }}$ or graduation which has resulted in lesser interest towards B.Ed. among students. It is suggested that minimum qualification for the post of teacher should be B.Ed. to recapture the lost identity of the course.

\section{Conclusion}

In concluding remark on the basis of collected data in this study we can say that no doubt there are both positive and negative results of increased duration of pre-service teacher training programme but can be fixed if above suggestion are taken care of. The concerned authority (NCTE and administration of training institutions) should give much importance to the quality rather than quantity of the programme. In addition to this teacher training programme should be 
made interested and lucent so that it catches the attention of choice based teachers rather than chance based teachers.

\section{References}

[1] Mangla, S. (2010). Teacher Education: Trends and strategies. New Delhi. Radha Publications.

[2] Position Paper (2005). National Focus Group on Teacher education for Curriculum Renewal. New Delhi NCERT.

[3] Government of India (1983). Report of the National Commission on Teacher-I, The Teacher and Society, Chattopadhyaya Committee Report. New Delhi: Ministry of Education

[4] Government of India (1993). Learning without Burden; Report of the National Advisory Committee. New Delhi: Ministry of Human Resource and Development.

[5] Retrieved from http://www.teindia.nic.in/reports_new.aspx,

[6] Retrieved from http://mhrd.gov.in/sites/upload_files/mhrd/files/document-reports/JVC\%20Vol\%201.pdf.

[7] epathshala.nic.in/wp-content/doc/NCF/Pdf/teacher_edu_final.pdf

[8] Kaku, D., Saini, D. (2015). Chattopadhyaya committee report (1983-85): recommendations and their relevance in today's scenario of teacher education. Abhinav National Monthly Referred Journal Of Research in Arts and Education, 04.

[9] Mondal, A., Saha, A., Baidya, M. (2015). National curriculum framework for teacher education, 2009: A review of its perspectives and relevanceness. International Journal Of Applied Research, 1(9), 776-778.

[10] Retrieved from http://www.teindia.nic.in/files/national_curriculu-for-teacher-education-2009.pdf.

*Corresponding author.

E-mail address: sunnyakash121@gmail.com 